\title{
11 Kenya's diplomacy and international relations within the IGAD region on matters of peace and security
}

\author{
Growth, development, and prospects
}

\author{
Kizito Sabala
}

\section{Introduction}

This chapter discusses the role and contributions of the Kenyan government on matters of peace and security within the Intergovernmental Authority on Development (IGAD) region. Though it deliberately omits bilateral relations with individual IGAD member states, it acknowledges that they do play out within the collective decisions at the level of IGAD. The chapter largely utilises secondary information in discussing relations with IGAD on matters of peace and security, particularly in relation to Somalia, Sudan, and the Sudan People's Liberation Movement/Army (SPLMoking at the future of the cou/A) conflict, and presently South Sudan. It concludes by lontry's diplomacy and international relations with international organisations in a highly globalised but equally competitive world, with emerging and more complex and sophisticated security threats, as the country hopes to assert its influence among the community of nations.

The creation of Intergovernmental Authority on Drought and Desertification (IGADD) in 1986 should be viewed as a response to larger integration efforts across the continent. The IGADD organisation was the brainchild of East African leaders from Djibouti, Kenya, Uganda, Ethiopia, Sudan, and Somalia in response to the shared problems associated with perennial ecological problems in the region, though almost three decades later, droughts, famine, floods, and desertification still abound. The change of IGADD to IGAD in 1996 was accompanied by an expansion of the organisation's mandate to include engagement in peace and security matters. Since then, Kenya has not only been an active member, having been a founder of IGAD, but has been influential in helping to transform the organisation to respond to a myriad of challenges, among them peace and security in the region. Although the organisation has engaged in other related peace and security challenges, such as transnational crimes, maritime security, and the Conflict Early Warning and Response Mechanism (CEWARN), among others, the most pronounced has been its role and contribution to the search for peace and security in war-torn Somalia, Sudan, and presently South Sudan. 


\section{Kenya and the IGAD peace and security norms and institutions}

The role and contributions of Kenya have been in tandem with the ever-changing peace and security architecture of the sub-region but also across the continent. Across the continent, Kenyans have been part of the UN peacekeeping operations in Namibia and Sierra Leone, and on the Eritrea-Ethiopia border. To be effectively engaged in peace and security, Kenya has been part and parcel of the development of relevant norms and institutions, including regional programmes. This includes the IGAD Security Sector Program (formerly the IGAD Capacity Building Program Against Terrorism), the 2002 Protocol on CEWARN, and the Mediation Support Unit (Sabala, 2013). In addition, Kenya has been involved in decisions at the highest policymaking level of the organisation to establish peace agreement implementation follow-up offices in Juba, Khartoum, and Mogadishu (IGAD Heads of State and Government Communiqués, 2008), following the realisation that on many occasions there was no sustained follow-up on the peace agreements once they have been signed.

Apart from being an active member in norm- and institution-building at continental and regional levels, Kenya, under the astute and able leadership of President Daniel arap Moi, was active in resolving the long-standing and protracted political conflict between the government of Sudan and the SPLM/A. During the 25-year civil war between the National Congress Party and the SPLM/A, following the abrogation of the 1972 Addis Ababa Agreement in 1983 by Sudanese President Gaffar Nimeiri, Kenya chaired the IGAD Sub-Committee on Sudan that pushed for the acceptance of the Declaration of Principles (DOP), which defined the broad agenda for negotiations between the two principal parties to the conflict. Together with other regional leaders who were members of the sub-committee - namely, Presidents Meles Zenawi of Ethiopia, Isaias Afwerki of Eritrea, and Yoweri Museveni of Uganda - ensured the sustainability of the peace talks. According to Lesch and Wöndu (2000), the DOP moved negotiations in a different direction from Abuja, inasmuch as the issue of self-determination for the South Sudanese was concerned. The Abuja process that took place between May 1992 and May 1993 is significant in two ways. First, it laid the foundation upon which the IGAD mediation proceeded, and secondly it brought the conflict in Sudan into international limelight. Odera adds that until the formulation of the DOP, it appeared that the IGAD mediation would be a tool for the parties.

The fact that mediators through the DOP had the courage to identify contentious issues such as self-determination, unity, and separation of state and religion showed that there was a clear intention to delve deeper into the fundamental issues at the heart of the conflict. The sub-committee was supported by, among others, Friends of IGAD and the IGAD Partners Forum (IPF), which initially comprised the Netherlands, Germany, Norway, Austria, Italy, Canada, the United States (US), and the United Kingdom. The main purpose of the IPF was to generate and galvanise international support for the IGAD-led mediation, but it was also instrumental in financing the process. After that, Kenya not only hosted a series of protracted talks in various parts of the country, such as Machakos, Naivasha, 
and Lake Bogoria, but also provided the special envoys - Dr Zachary Onyonka, Ambassador Daniel Mboya and Gen. Lazarus Sumbeiywo - who mediated the process on behalf of IGAD. The result of these efforts was the Comprehensive Peace Agreement (CPA) of 2005 that ended one of the longest-standing civil wars in Africa. Before the process that led to the CPA, which officially and de facto ended the civil war in Sudan, there were numerous attempts at peace-making in Sudan. These included negotiations in Addis Ababa, Ethiopia (August 1989); Nairobi, Kenya (September 1989); Abuja, Nigeria (May-June 1992, April-May 1993); Nairobi (1993), and Frankfurt, Germany (January 1992) (Public Affairs Council, 2002). In 1993, the government of Sudan requested IGAD to mediate in the conflict following the collapse of the Abuja process which was attributed to what was termed the irreconcilable position of the two parties on the question of state and religion (Odera, 2002). According to Odera (2002), the mediators at Abuja performed a diagnostic role and were able to tease out the main issues on which resolution depended.

Kenya was instrumental in preparing the ground for the IGAD mediation in Sudan (Communiqué, 1993). In its engagement in the Sudan-SPLM/A conflict, the country was guided by the principle of good neighbourliness, providing assistance to its neighbours to be at peace with itself and with its neighbours, and seeking peaceful means such as dialogue to resolve disputes. In this regard, Kenya held meetings with Hassan El Turabi and Omar al-Bashir as the leaders of the National Congress Party (NCP) in Sudan and John Garang of SLPM/A in Addis Ababa and Nairobi where the latter was urged not to put all his "eggs in one basket," a specific reference to the use of the military option alone, which he had sworn to employ in liberating the Southern Sudanese. Instead, Garang was convinced to embrace both military action and dialogue to resolve the conflict. Kenya took it upon itself to raise awareness on the plight of the South Sudanese under discriminatory treatment by the NCP-led government in Khartoum at national, regional, and international levels. The IGAD Peace Initiative was established In September 1993 and launched in March 1994 to assist in bringing the conflict to an end.

According to the interview the writer of this chapter had with Peter Marwa, the former IGAD Head of Conflict Resolution and Bethwel Kiplagat in Nairobi, in 2012, President Moi, in his capacity as the chair of the IGAD Sub-Committee on Peace in Sudan was instrumental in ensuring that the process was sustained. He convened numerous IGAD summits on Sudan, made several personal visits to Khartoum, and met with Garang and Bashir to stress the importance of dialogue to resolve the conflict. Moi's personal commitment to the process negated the accusations levelled against IGAD that it was a dishonest and partial broker. His personal dedication also helped to galvanise and mobilise international partners to support the process. Furthermore, he ensured that the conflict and suffering of Sudan were kept alive on both regional and international agendas. Even at the lowest point in the process, when some actors were being accused of either bias or undermining the process, Garang and Bashir had something good to say about Moi. 
President Moi maintained the unswerving support of the Kenya government to the peace process to resolve the conflict between the government of Sudan and SPLM/A. For instance, when the development partners questioned the transparency and accountability of the financial resources that were supporting the peace process and suspended funding, the Kenyan government injected USD \$66 million to sustain the process until it was resumed (Sabala, 2012). Throughout the entire process, Moi supported the IGAD special envoys and personally took over leadership when the need arose to give it impetus. During the negotiations, Moi ensured he was well equipped and informed with the latest accurate developments regarding the process, a situation that earned him respect and trust when he proposed interventions to overcome any impasse. Even when he left power in 2002, not only did he continue to work on Sudan through the Moi Foundation, but his successor Mwai Kibaki appointed him as his special envoy on Sudanese matters. Ambassador Bethuel Kiplagat noted that Moi was passionate about peace in Sudan. His religious belief inspired this virtue in promoting peace and a strong belief in the principle of African solutions to African problems and prestige. ${ }^{1}$

At some point during negotiations, when frustration-gripped infighting intensified in parts of Sudan, and there was no significant progress on the mediation front, and the humanitarian situation was worsening, Moi sent a message to the two parties indicating that unless there was meaningful progress, he was not going to preside over the process. The statement, which carried both an appeal to the parties and a threat to withdraw, did not achieve its intended goal as the session ended in a stalemate. The CPA is a conglomeration of six protocols on various issues that include security arrangements, power and wealth sharing, and the question of the oil-rich border area of Abyei, among other things, and two annexes. Furthermore, the Kenyan government provided financial resources to keep the process afloat when development partners delayed their support.

\section{Kenya and the South Sudan conflict}

During the crisis that broke out in South Sudan on 15 December 2013, Kenya hosted the first IGAD summit on 27 December on the matter, following a flurry of shuttle diplomacy that involved the country's cabinet secretary for foreign affairs and the Ethiopian minister for foreign affairs. The summit laid the foundation for the commencement of negotiations between the SPLM in the Government and the SPLM in the Opposition (SPLM-IO), former detainees, and other political parties. The former detainees were, namely, Deng Alor Kuol, Gier Chuang, Kosti Manibe, Chol Tong Mayay, Cirino Hiteng, Madut Biar Yel, and John Luk Jok. The others were Pagan Amum Okiech, Majak D’Agoot, Oyai Deng Ajak, and Ezekiel Lol Gatkuoth. They were detained in Juba by the South Sudan government because they were accused of being part of the (Riek Machar of SPLM-IO) plot to overthrow the government of Salva Kiir. When the crisis broke out on 15 December 2013, the South Sudan government accused Riek Machar of plotting to overthrow the government though the latter denied the accusations. 
The negotiations took place in Addis Ababa, Ethiopia, led by three special envoys - namely, Ambassador Seyoum Mesfin of Ethiopia, Gen. Mohammed Ahmed Mustafa al-Dhabi of Sudan, and Gen. Lazarus Sumbeiywo of Kenya - culminated in the final Agreement on the Resolution of the Conflict in the Republic of South Sudan (ACRISS) in August 2015. During the negotiation process, the regional organisation in which Kenya served as the rapporteur and Ethiopia as the chair convened more than ten Extraordinary Summits of Heads of State and Governments on the question of South Sudan.

The IGAD mediation process on South Sudan was structured as follows: the summit, which is the highest decision-making policy organ of the organisation and set the overall direction of the talks, met more than ten times - a clear demonstration of its political commitment to see the conflict end peacefully. With Kenya as the rapporteur and Ethiopia the chair, the involvement of Ugandan military and allegations that Sudan was siding with the opposition, the region's collective voice had been undermined. The Council of Ministers consisted of the ministers of foreign affairs of the member states, and their meetings preceded every summit and the differences at summit level reflected what transpired at the council level.

The Office of the Special Envoys on South Sudan (OSSESS) was the most critical organ in the mediation process. It oversaw day-to-day negotiations and reported to the council and the summit. It was created at the Nairobi summit of 27 December 2013 (IGAD, 2013) and comprised the three special envoys, chaired by Ambassador Mesfin. The IGAD Monitoring and Verification Mechanism (MVM) was provided for at the 23rd Extraordinary Session of the IGAD Assembly of Heads of State. It had headquarters in Juba, with teams in selected conflict zones, whose mandate was to monitor and verify violations of the cessation of hostilities agreement and report to the OSSESS. MVM was also responsible for monitoring and verification of humanitarian access, protection of civilians, and cessation of hostile propaganda. Moreover, the teams had the leverage to use their discretion and deploy verification missions on the basis of credible information, complaints submitted by the parties to the conflict, and/or direct requests from the IGAD special envoys; and monitor the activities of the parties and acts associated with their forces and armed groups and allied forces invited by either side. The final organ was the IGAD Secretariat, which continued to play a very peripheral role, despite having seconded the director of peace and security to be fully engaged in the process, while the whole mediation was supposed to be anchored within the newly established Mediation Support Unit.

Kenya is part of the Joint Monitoring and Evaluation Commission and Ceasefire and the Transitional Security Arrangements Monitoring Mechanism (CTSAMM), which are transitional structures that were expected to nurture and support the Transitional Government of National Unity (TGNU) in South Sudan in navigating through a transitional period. CTSAMM replaced the former Joint Technical Committee/MVM, which was monitoring the ceasefire agreements signed by the two parties before the 2015 agreement in which Kenya was participating.

Furthermore, when a dispute broke out between soldiers allied to President Salva Kiir and Vice President Riek Machar on 7 July 2016 within the TGNU, 


\section{Kizito Sabala}

Kenya hosted the First Extraordinary IGAD Council of Ministers on the situation in South Sudan to try and resolve the matter. Kenya was part of subsequent meetings on the same matter on the side-lines of the AU summit in Kigali, Rwanda, in July and Addis Ababa in August. Even when violence broke out in Juba in July between the two factions, Kenya hosted the extraordinary IGAD council meeting. The council's hard-hitting communiqué (IGAD, 2016) was not only adopted by the AU Peace and Security Council but was further improved at the IGAD Extraordinary Summit in Kigali.

In addition to the foregoing, Kenya contributed more than 1,300 peacekeepers to the UN Mission in South Sudan (UNMISS) and provided the force commander. A spat occurred following the dismissal from that role of Lt. General Johnson Ondiek. A UN investigation panel blamed poor leadership and judgment for attacks on Terrain Camp, a UN facility in the capital, Juba, which led to several deaths. Although the UN promptly requested that Kenya appoint a replacement, the country considered it unnecessarily punitive and refused. However, following consultations with the new UN Secretary-General António Guterres, the country, as an important interlocutor in drawn-out efforts to rescue South Sudan, recommitted itself to supporting peace efforts there.

Bilaterally, Kenya continued to engage and encourage the TGNU to respect the institutions that were established during this period. Kenya has continued to closely monitor the implementation of this agreement through Track II (backchannel) diplomacy and ensure that that the parties to the agreements respected the accord reached in August in Addis Ababa.

\section{Kenya in Somalia}

Just as in South Sudan, Kenya has been an important player in trying to resolve the Somali conflict. The search for sustainable peace and security in that country, which has been without an effective government since the fall of Mohamed Siad Barre in 1991, has been particularly challenging and difficult. Against this backdrop, Kenya has been at the forefront of efforts to deal with more than two decades of state failure and political anarchy that allowed a culture of warlordism to become entrenched. This has since been replaced by Al-Shabaab's militant Islamist extremism, which continues to make Somalia ungovernable; a situation that has been conducive to creating an environment where lawlessness, criminal activities, trafficking, and smuggling thrive.

Kenya hosted, mediated, and led the process in Nairobi in 2004 that created the first semblance of a government in the post-Said Barre era. It provided the chief mediators, Elijah Mwangale and Ambassador Bethuel Kiplagat, who spearheaded the process. The country contributed 3,664 troops in Somalia (Daily Nation, 2016) as part of the 22,000-strong African Union Mission to Somalia (AMISOM) created in 2007 to help stabilise the war-torn country. Uganda had the highest contingent $(6,223$ troops), followed by Burundi $(5,432)$, Ethiopia $(4,395)$, and Djibouti $(2,000)$, though lately there were concerns about the effectiveness of AMISOM in dealing with Al-Shabaab. 
However, there seems to be a need to re-examine Kenya's military venture into Somalia, dubbed Operation Linda Nchi, given the heavy casualties that the country has sustained since its entry in 2011. Kenya has witnessed increased terrorist attacks by the Al-Shabaab militant group on its soil, since the intervention of Kenya Defence Forces (KDF) in Somalia in 2011. The worst attack happened in 2016 when the Kenyan base at El Ade was attacked resulting in the death of more than 150 Kenyan soldiers (BBC 2016).

Part of AMISOM, the presence of the Kenyan soldiers should be re-evaluated against the backdrop of allegations of its involvement in sugar and charcoal smuggling in Somalia. Its losses to Al-Shabaab, the implications of frequent terrorist attacks on the Kenyan economy, and the need for a reconstructed AMISOM also need evaluation. The UN report (Kelley, 2017) on the charcoal and sugar smuggling and its implications for the country's military relationship - if any with Al-Shabaab, requires crafting a face-saving policy of withdrawal or an exit strategy.

Kenya hosts about 600,000 Somali refugees (Huffington Post, 2016) in Kakuma and Dadaab camps as it did southern Sudanese during the 21 years of the liberation struggle in that country. In the recent past, Kenya has raised serious concerns about links between Somali refugees and national security and resolved to start a process of repatriation to their country. Discussions took place between the government and the UN on this issue. In response to perceived threats posed by the Somali refugees, Kenya hosted an IGAD summit on 26 and 27 March 2017 that discussed ways and means of addressing their problems within the confines of the international conventions relating to the protection, treatment, and repatriation of displaced persons.

During the special summit, the IGAD Heads of State and Government, which included the then newly elected Somali President Mohammed Abdullahi "Farmajo" Mohamed and the AU Commission Chair Moussa Faki Mahamat, agreed to collectively pursue a comprehensive regional approach to deliver durable solutions to the issues regarding Somali refugees. The summit also appealed for the protection of refugees to respond effectively to the ravaging drought situation in the sub-region, mobilise resources, and coordinate international efforts.

Kenya played a role in the formation of regional states or federal states in Somalia and supported capacity-building in various fields. It occasionally hosted various inter-community dialogues that led to the formation of the Jubaland Transitional Government. At bilateral and multilateral levels Kenya provided capacity-building to both Somalia and South Sudan using its institutions and seconding civil servants in the areas of policing, banking, military intelligence, and ICT, among others. However, its efforts to resolve the Ugandan conflict was a failure. Before Kenya's engagement in the Sudan-SPLM/A conflict, the country had tried to mediate in Uganda in the conflict between the National Resistance Movement (NRM) and the government of Gen. Basilio Olara Okello. This process did not see the light of the day, as the NRM took power in Uganda in 1985 on the eve of negotiations in Nairobi. 


\section{Kenya and IGAD}

After the post-electoral violence in 2007-2008 in the country and the eventual confirmation of charges (crimes against humanity) against President Uhuru Kenyatta and Vice President William Ruto, by the International Criminal Court (ICC), which held that they had a case to answer, Kenya was able to lobby, mobilise, and rally not only IGAD member states but also the AU on the question of the ICC. This should be situated within the broader debate of Africa-West relations and the whole notion of neo-colonialism, but also the specific context that Kenya was experiencing at that point in time. The country, through IGAD and the $\mathrm{AU}$, successfully piled pressure on the ICC that later terminated the cases against Kenyatta, Ruto, and journalist Joshua Arap Sang, terming it a mistrial. Though the mobilisation kept the issue of Africa-ICC relations alive on the international and continental agenda, it received a blow during the July 2016 AU Summit in Kigali, which was sharply divided on the proposal for a mass withdrawal from the Rome Statute by the continent's member states if it was not revised.

\section{Challenges and opportunities for Kenya's diplomatic engagement}

One of the main challenges undermining the country's path towards reclaiming its politically dominant space in the region is the fractured and deep-seated ethnically based political differences that continue to undermine the fabric of the country's economy. The country's political chessboard is highly ethnicised and built on unresolved historical injustices relating to land and political marginalisation in the pursuit of political power (Government Printer, 2008b). These issues that cloud and mask the country's political scene have been swept under the carpet for political greed and unless addressed could plunge the country into political and economic instability and turmoil. These issues have polarised the country's political landscape, particularly during the period heading into elections, a situation that potentially scares away long-term investors.

A second challenge that impacts on the country's international relations and diplomacy is occasional terrorist attacks. Apart from Somalia, the bedrock of the Al-Shabab militants in the Horn of Africa, Kenya has been hardest hit by terror attacks. This is attributed to weak institutional and capacity deficits to deal with the problem, though other reasons are a large Somali population that has kin and kith across the long, expansive border; and unemployment and high levels of poverty, which make it easy for extremist groups to find recruits.

There is also the problem of belonging to several regional groupings in the same geographical location with similar mandates and aspirations. For instance, the country belongs to the Common Market for Eastern and Southern Africa (COMESA), the EAC, and IGAD. The problem arises when states have to split their financial contributions to remain active in the affairs of these groupings, a fact that partly explains why so many of them are in arrears, but also why significant funding of programmes is at the benevolence of development partners. Another 
challenge relates to the fact that Kenya's relations with IGAD as an organisation must take into account the foreign policies and behaviour of individual member states, particularly where an individual member state seems to be driven by its own interests, unlike the collective ones as a regional grouping.

Despite the challenges, there are several opportunities that the country can exploit to improve its regional and international engagement with the rest of the world. The main opportunity for addressing these fissures is the 2010 constitution that has come with various institutions; but the notion of the "tyranny of numbers" in a National Assembly allied to whoever assumes power in the country remains a serious threat to its implementation. This is because they use their numbers in the National Assembly to amend some of the clauses in the constitution to suit the ruling elite.

The days when political elites will just make foreign policy decisions without convincing the populace that it is the right thing to do are over. In short, the country's diplomacy and international relations must be a function of domestic politics and aspirations. This is partly due to a highly educated and active middle class, and a politically sensitive population that includes a strong civil society, religious community, and private sector, including a strong clique of Western diplomats who are ever vocal on matters that may threaten the stability of the nation.

Kenya, with its extensive experience in regional, African, and global peacekeeping missions and peace-making, remains a critical player in the East African security equation. It not only has massive experience in mediation, but also the country's armed forces have been part of UN peacekeeping missions in Angola, Sierra Leone, East Timor, and the former Yugoslavia, to mention but a few.

\section{Concluding remarks}

There is no doubt that the country will continue playing a pivotal role in East Africa, given not only its strategic location but, more importantly, a relatively developed economy and a wealth of experience that it has culminated in hosting the Sudanese, South Sudanese, and Somalia peace talks and refugees. As a founding member of IGAD, Kenya is a major player in the sub-region's peace and security architecture. Until recently, East Africa's most advanced economy serves as a rapporteur of IGAD, which is mediating conflicts in the Horn of Africa, most recently during the strenuous negotiations between the warring parties in South Sudan. The country has also invested in South Sudanese service industries, such as insurance, banking, ICT, and hospitality. Also, there are many students not only in Kenya's institutions of higher learning but also in basic education.

The country needs to revisit its approach to regional and international politics, diplomacy, and international relations, but more importantly knock out sectarian considerations from foreign relations. The country's embassies should not be polarised on ethnic and sectarian lines if they are to take advantage of the tremendous academic and intellectual resources of Kenyans abroad. The process of building solid and effective diplomacy and international relations is seldom a smooth one and sometimes it is marred by terrible disappointments. Kenyans in 
key positions in various international organisations such as the EAC, COMESA, IGAD, the AU, and the World Trade Organization, among others, need to be the country's ambassadors to support the president and career diplomats to steer the country in international and regional arenas.

The country's relations with its neighbours have been premised on the principle of good neighbourliness and resolving disputes through dialogue and peaceful means. These principles and values are reiterated and reinforced in the country's two documents on diplomacy and international relations, namely Kenya's Foreign Policy (2014) and the Kenya Diaspora Policy (2014), the first of their kind to have been written and which elaborate how the nation has conducted international affairs since independence. The documents reaffirm the long-standing practice of promoting sub-regional and regional integration and cooperation, enhancing regional and global peace and security, and promoting international cooperation and multilateralism. This recognises that the country is an integral part of the African continent, whose national interests are intrinsically linked to Africa's stability, unity, and prosperity.

The above is aptly captured in the documents, the guiding value among them being the resolution of conflicts by peaceful means, which speaks to the peace and diplomacy pillar. Other pillars are economic, diaspora, environmental, and cultural. The objectives of the peace and diplomacy pillar are: (1) to promote the resolution of conflicts by peaceful means; (2) to collaborate with other African countries to strengthen the conflict prevention, management, and resolution capacity of regional institutions, including the EAC, IGAD, COMESA, and the $\mathrm{AU}$ (with the aim of promoting sustainable peace and development; (3) to support peace efforts by the AU and the UN through contributing troops and providing leadership in peacekeeping missions within the continent and globally; and (4) to create conflict analysis and prevention capacity nationally and in the region through the Foreign Service Academy. These values and principles should be the cornerstone of the country's diplomacy and international relations in the next decade and beyond.

Finally, this chapter concludes that the country's foreign relations within the IGAD sub-region since independence, as with other actors in the international system, have been influenced by mainly six interrelated factors. These are colonialism; Cold War politics; the principle of non-interference; good neighbourliness; the emerging globalisation; and the post-Cold War political climate, including the idiosyncratic beliefs and world views of the political elite that have dominated the county's political terrain. The country's foreign relations in the next decade and beyond will also be a function of the foreign policies and behaviour not only of its immediate neighbours within IGAD and the EAC but also the effect of globalisation and emerging actors in African affairs such as China, Japan, and India. This will be in addition to the political elite in the country and the 2014 Foreign Policy document.

Kenya is a major interlocutor in the drawn-out efforts to rescue South Sudan and Somalia, having hosted numerous IGAD summits to set the stage for several peace agreements, but it has also provided mediators. The country has also 
contributed troops to AMISOM, as it has done to UNMISS, as well as to the UN mission in Darfur. In the case of Somalia, Kenya has remained a centre for coordinating and delivering much-needed relief to Somalis and some level of reconstruction and rebuilding programmes in the country. Kenya should continue engaging in the search for sustainable stability in the IGAD region to address both the challenges of peacebuilding and post-conflict reconstruction. These challenges in countries that have experienced long periods of civil war and destruction are enormous and include demilitarisation, disarmament, demobilisation and reintegration, economic reconstruction, and social cohesion, and require both regional and international support.

\section{Note}

1 Author's interview with Ambassador Bethuel Kiplagat.

\section{References}

African Union Commission. (2000). Constitutive Act of the African Union, in African Union Instruments Relating to Peace and Security, African Union Commission, Addis Ababa, Ethiopia.

BBC. (2016). Somalia's Al-Shabab Killed '180 Kenyan Troops' in el-Ade. Retrieved April 8, 2019 from https://www.bbc.com/news/world-africa-35658500

BBC News. (2016). What Happened When Al-Shabab Attacked a Kenyan Base in Somalia?, by Tomi Olandipo, 22 January 2016. https://www.bbc.com/news/world-afri ca-35364593 (accessed 22-10-2020).

European Sudanese Public Affairs Council. (2002). The Search for Peace in the Sudan: A Chronology of the Sudan Peace Process. Retrieved April 9, 2019 from https://sudanmi ssion.ch/en/documents/peacesudan

Government Printer. (2008a). Report of the Commission of Inquiry into Post Election Violence. Government Printer, Nairobi, Kenya.

Government Printer. (2008b). Report of the Independent Review Commission on the General Elections Held in Kenya on 27 December 2007. Government Printer, Nairobi, Kenya.

IGAD. (2013). Communiqué of the 23rd Extraordinary Session of the IGAD Assembly of Heads of State and Government on the Situation in South Sudan State. IGAD, Nairobi, 27 December.

IGAD. (2016). Communique of the 56th Council of Ministers on the Situation in South Sudan. IGAD, Djibouti.

IGAD. Communiqués and Decisions of 1993 and 2008. IGAD, Djibouti.

Intergovernmental Authority on Development (IGAD). (1994). Declaration of Principles. IGAD, Nairobi, Kenya.

Kelley, K. (2017). UN Urges KDF to Stop Somalia Charcoal Export. Business Daily. Retrieved April 8, 2019 from https://www.businessdailyafrica.com/news/UN-urgesKDF-to-stop-Somalia-charcoal-export/539546-4188766-sllmd4z/index.html

Lesch, A. and Woundu, S. (2000). Battle for Peace in South Sudan: An Analysis of the Abuja Conferences 1992-1993. University Press of America, Lanham, MD.

Ministry of Foreign Affairs and International Trade. (2014). Kenya's Foreign Policy. Ministry of Foreign Affairs and International Trade, Nairobi Kenya. 
Odera, J. (2002). Intervening in African Internal Conflicts in Post-Cold War Era 19901999: A Case Study of the IGAD Mediation of the South Sudan conflict (Unpublished $\mathrm{PhD}$ dissertation). Ghent University, Belgium.

Sabala, K. (2012). Assessing the Design and Architecture of Peace Accords in Africa: Best Practices and Challenges: The IGAD Mediation of Sudan Comprehensive Peace Agreement. Paper prepared for the UNECA/GPAD. Addis Ababa, Ethiopia.

Sabala, K. (2013). Conflict, Environmental Security and Governance among the Pastoralists in Kenya: A Case Study of the Turkana Community (Unpublished PhD Dissertation). Nairobi: University of Nairobi.

Sabala, K. and Ukeje, C. (2017). Revisiting the Dismissal of the UNMISS Force Commander in South Sudan (APN Briefing Note, Number 10, April). Social Science Research Council, New York. 